\title{
Effects of Fusarium toxin contaminated wheat grain and of a detoxifying agent on rumen physiological parameters and in sacco dry matter degradation of wheat straw and lucerne hay in wethers
}

\author{
S. Dänicke \\ Institute of Animal Nutrition, \\ Federal Agricultural Research Centre (FAL) Braunschweig \\ Bundesallee 50, D-38116 Braunschweig, Germany
}

(Received 25 March 2002; accepted 2 August 2002)

\begin{abstract}
Wethers equipped with a rumen fistulae were subjected to four dietary treatments in consecutive experiments. The treatments consisted of rations containing wheat grain and pasture hay at a ratio of 1 to 1 on a dry matter basis. Two wheat grain batches were fed either in the absence or presence of a detoxifying agent (Mycofix Plus, Biomin GmbH, Herzogenburg, Austria). Onc wheat grain batch served as the uncontaminated control wheat whereas the other batel contained the Fusarium toxins deoxynivalenol (DON) and zearalenone (ZON) at concentrations of approximately 10 and $0.76 \mathrm{mg}$ per $\mathrm{kg}$ dry matter, respectively.

Parameters of rumen fermentation such as the molar ratios of short chained volatile fatty acids and ammonia concentration in rumen fluid remained unchanged in response to dietary treatments whereas the detoxifying agent exerted a rumen $\mathrm{pH}$-buffering effect. This effect was independent of the mycotoxin contamination of the wheat. The $\mathrm{pH}$-differences in rumen fluids collected from wethers fed the MP-supplemented and unsupplemented rations amounted 0.2 to 0.3 on average in the time period between 1.5 and $5 \mathrm{~h}$ after feeding.

The kinetic profile of the in sacco dry matter degradation revealed a reduced degradation rate for wheat straw incubated in wethers fed the mycotoxin contaminated rations whereas no changes were obvious when lucerne hay was incubated. The detoxifying agent had no effect on the kinetics of dry matter degradation.

It can be concluded that feeding of rations containing approximately $4.6 \mathrm{mg}$ of DON and $0.34 \mathrm{mg}$ ZON per kg of complete ration at a reference dry matter content of $88 \%$ does not impair rumen fermentation although there was a trend for a decrease in the rate of dry matter degradation of the slowly degradable wheat straw. The pH-buffering effects of the detoxifying agent were mycotoxin independent.
\end{abstract}

KEY WORDS: Fusarium toxin, rumen parameters, in sacco, degradability 


\section{INTRODUCTION}

Among farm animals, ruminants are regarded as relatively resistant to the Fusarium toxin deoxynivalenol (DON). The critical dictary DON-concentrations at a reference dry matter content of $88 \%$ are $1 \mathrm{mg}$ per $\mathrm{kg}$ for pigs, $2 \mathrm{mg}$ per $\mathrm{kg}$ for pre-ruminant calves and $5 \mathrm{mg}$ per $\mathrm{kg}$ for gallinaceous poultry and ruminants (BML, 2000). In vitro studies using rumen fluid have shown that rumen microbes are capable of degrading DON (King et al., 1984; Swanson et al., 1987; Razzazi et al., 2000) by cleaving the epoxide group of the molecule which means a loss in toxicity. Therefore, the rumen is regarded as a pre-systemic protection mechanism in ruminants. On the other hand, it is also well known that mycotoxins are able to exert anti-microbial properties (for review Trenholm et al., 1989). This in turn, could have an impact on the profile and/or activity of rumen microbes and consequently on ruminal nutrient utilization.

So-called detoxifying agents, which are added to the diet, are supposed to avoid absorption of mycotoxins from the gastro-intestinal tract by strong binding on their surface (adsorption). Although certain mycotoxins are degraded by rumen microbes there could also be a need for using such adsorbents in ruminant nutrition. Since several mycotoxin degradation products still exert toxic properties, they bear the danger of being transferred to milk. Hence, several efforts have been made to block the transfer of Aflatoxin $M_{1}\left(A F M_{1}\right)$, a ruminal degradation metabolite of Aflatoxin $\mathrm{B}_{1}$, to milk. The results are somewhat conflicting. Blüthgen and Heeschen (1990) and Blüthgen and Schwertfeger (2000) were not able to substantially decrease the AFM transfer to milk by feeding bentonite or glucomannans, whereas Diaz et al. (1997) were able to demonstrate a reduction in carry over by feeding bentonite and a yeast preparation.

On the other hand, several adsorbing clays are also known to increase rumen $\mathrm{pH}$ due to their capability for ion exchange and their proton attracting properties. Thus, both an adsorbent, and Fusarium toxins such as DON could influence the rumen characteristics and consequently the capacity of microbes for nutrient utilization.

Therefore, the aim of the present study was to examine the effects of feeding an uncontaminated control wheat and of a Fusarium toxin contaminated wheat both in the absence and in the presence of a detoxifying agent on rumen fermentation parameters and on in sacco dry matter degradability.

\section{MATERIAL AND METHODS}

\section{Experimental design and procedure}

Two wheat grain batches were used in the experiments. The first batch contained only small amounts of the Fusarium toxins DON and zearalenone (ZON) 
and served as control wheat whereas the second batch was naturally contaminated, especially with DON (Table 1).

TABLE 1

Chemical composition of ration components and of incubated feedstuffs

\begin{tabular}{|c|c|c|c|c|c|}
\hline & \multicolumn{3}{|c|}{ Ration components } & \multicolumn{2}{|c|}{ lncubated feedstuffs } \\
\hline & $\begin{array}{l}\text { control } \\
\text { wheat } \\
\text { grain }\end{array}$ & $\begin{array}{c}\text { Fltsarium } \\
\text { toxin } \\
\text { contaminated } \\
\text { wheat grain }\end{array}$ & $\begin{array}{c}\text { pasture } \\
\text { hay }\end{array}$ & $\begin{array}{l}\text { wheat } \\
\text { straw }\end{array}$ & $\begin{array}{c}\text { luccme } \\
\text { hay }\end{array}$ \\
\hline Dry matter, $\mathrm{g} / \mathrm{kg}$ & 870 & 865 & 872 & 935 & 924 \\
\hline $\begin{array}{l}\text { Nutrients, g/kg DM } \\
\text { crude protein }\end{array}$ & 124 & 145 & 135 & 64 & 157 \\
\hline crude fat & 18 & 10 & 10 & 13 & 9 \\
\hline crude fibre & 23 & 41 & 279 & 471 & 284 \\
\hline $\mathrm{ADF}$ & 33 & 45 & 285 & 514 & 308 \\
\hline NDF & 111 & 148 & 544 & 801 & 393 \\
\hline $\mathrm{N}$-free extractives & 816 & 782 & 477 & 386 & 391 \\
\hline \multicolumn{6}{|l|}{ Mycotoxins } \\
\hline Deoxynivalenol, mg/kg DM & 0.2 & 10.3 & $<0.04$ & $<0.04$ & $<0.04$ \\
\hline Zearalenone, $\mu \mathrm{g} / \mathrm{kg}$ DM & 3 & 764 & n.a. & n.a. & n.a. \\
\hline
\end{tabular}

n.a. $=$ not analyzed

The additive Mycofix ${ }^{6}$ Plus (MP), (Biomin GmbH, Herzogenburg, Austria), was used as detoxifying agent. It is a combination product and contains enzymatic activitics for degradation of DON in addition to the adsorbing component according to the manufacturer (Pasteiner, 1998).

Three 3-years old Black-Faced mutton shcep wethers weighing $89 \mathrm{~kg} \pm 4 \mathrm{~kg}$ were used. Animals were equipped with a permanent rumen fistulae with an inner diameter of $35 \mathrm{~mm}$. Each of the 4 experiments consisted of 35 days in total. The first 21 days served for adaptation to the respective rations whereas the remaining 14 days were used for the in sacco trials and rumen fluid sampling.

The rations were composed of hay and of the respective wheat grain batch at a ratio of 1 to 1 on a dry matter basis. Wheat grain was ground on a hammer mill whereas hay was coarsely cut into pieces of approximately 5 to $15 \mathrm{~cm}$ length. Rations were completed by the addition of $30 \mathrm{~g}$ of a mineral premix and daily dry matter intake was restricted to approximately $1.2 \mathrm{~kg}$ to avoid refusals. Consequently, rations were not balanced for differences in nutrient composition of the control and contaminated wheat. Daily ration was fed in two equal portions at $7.00 \mathrm{a} . \mathrm{m}$. and at $2.30 \mathrm{p.m}$.

Uncontaminated wheat was fed during the first two experiments with the addition of $5 \mathrm{~g}$ of MP supplemented per $1 \mathrm{~kg}$ of wheat during the following two expe- 
riments. After finishing the second experiment, a re-creation period of 28 days was intercalated in which only hay was fed before the Fusarium toxin contaminated wheat was tested without or with addition of MP.

Rumen fluid samples were taken via the fistula at day 21 of feeding a particular ration by using a syringe connected to a rubber probe. Samples were taken just before the morning feeding and following at $0.5,1,1.5,2,2.5,3$ and $5 \mathrm{~h}$ after the begin of the meal; $\mathrm{pH}$ was immediately measured in all samples (digital $\mathrm{pH}$-measurement device, $\mathrm{pH} 525$, WTW) whereas the sample which was taken after $3 \mathrm{~h}$ was further processed for measurement of ammonia and volatile fatty acids.

Nylon bag technique was carried out according to the principles outlined by Mchrez and Ørskov (1977) and Flachowsky et al. (1988). The nylon bag incubations for determination of dry matter degradation kinetics started at day 22 of each experiment. Lucerne hay and wheat straw were used as quickly- and slowly-degradable matcrial, respectively. Incubation material was milled (Retsch) to pass a $3 \mathrm{~mm}$ screen before being used for incubations. Nylon bags with a size of $50 \mathrm{~mm} \times 130 \mathrm{~mm}$ (Bar Diamond Inc., Idaho, USA) had a mean pore size of $53 \mu \mathrm{m} \pm 10 \mu \mathrm{m}$. Air dried feedstuff samples of approximately $1.5 \mathrm{~g}$ were weighed in the bags, which resulted in a sample density of 10 to $15 \mathrm{mg}$ per $1 \mathrm{~cm}^{2}$ bag surface. Bags were sealed with plastic cable binders. Eight bags in total were fixed on a $50 \mathrm{~cm}$ long and flexible wire insulated with plastic in such a way that bags filled with wheat and lucerne hay were alternately fixed. Samples were incubated for $8,16,24,48,72$ and $96 \mathrm{~h}$ according to the batch mode, which meant that fistulae remained sealed during incubations. After incubations, bags were rinsed with cold tap water and subsequently washed twice using an automatic washing machine. In addition, 12 non-incubated samples of each feedstuff were treated in a similar way in order to determine the washing losses. Weight of bags was recorded after drying to a constant weight at $105^{\circ} \mathrm{C}$.

\section{Analysis}

Chemical composition of feedstuffs was analyzed according to the methods of the VDLUFA (Naumann and Bassler, 1993). Deoxynivalenol in feedstuffs was analyzed by HPLC with diode array according to a modified sample preparation procedure as advised by Coring System Diagnostix GmbH (Gernsheim, Germany) (Mycosep ${ }^{\mathrm{TM}}$ trichothecene). The mean recovery rate for feedstuffs was $72 \%$ and results of analysis were not corrected for this recovery. Zearalenone was determined by HPLC with fluorescence detection after treatment with $2 \mathrm{U} \beta$-glucosidase (E.C. 3.2.1.21, Sigma, Deisenhofen, Germany, No. G-0395) according to Ueberschär (1999). Results were not corrected for recovery, which was $95 \%$.

Ammonia- $\mathrm{N}$ in fresh rumen fluid was analyzed by a modified Conway-method as described by Voigt and Steeger (1967), using a micro diffusion vessel. Volatile fatty acids in rumen fluid were determined according to Geissler et al. (1976) using 
a gas chromatograph (Hewlett Packard 5580, Avondale, PA, USA) equipped with a flame ionization detector. Fatty acids were separated by a column containing $15 \%$ dioctyl-debacinate and sebacinic acid on fused silica as the stationary phase.

\section{Statistics}

All data were analyzed by a two-way analysis of variance (ANOVA) using the model:

$$
y_{i j k}=\mu+a_{i}+b_{j}+(a x b)_{i j}+c_{i j k}
$$

where $y_{j, j}=$ parameter of an observation $k$, subjected to wheat type $i$ and detoxifying agent $j ; a_{i}=$ wheat type (not contaminated, mycotoxin-contaminated); $b_{\text {, }}$ $=$ detoxifying agent (without, with Mycofix $\left.x^{i p l} P l u s\right) ;(a x b)_{i j}=$ interactions; $e_{i j k}=$ error term.

The relative dry matter loss of wheat straw and lucerne hay was fitted to the regression equation of Orskov and McDonald (1979):

$$
P=a+b\left(1-e^{-c t}\right)
$$

where $\mathrm{P}=$ the dry matter degradation at time $\mathrm{t}, \mathrm{a}=$ soluble fraction or washing loss, $b=$ potential degradable fraction, $c=$ rate constant of fraction $b$

Experimentally determined dry matter washing losses of wheat straw or lucerne hay coincide with the intercept of the regression on ordinate at time zero (parameter "a"). Consequently, these measures are independent of the 4 examined rumen conditions induced by feeding of wheat, wheat $+\mathrm{MP}$, contaminated wheat or contaminated wheat + MP. Hence, a multiple approach of the regression was applied which cnabled the simultaneous estimation of the parameters " $b$ " and " $c$ " separately for each of the 4 dietary treatments and of the common intercept on ordinate, i.e. all 4 treatments were forced through the same intercept and contributed to this estimate.

Effective dry matter degradation was calculated according to Ørskow and McDonald (1979):

$$
\text { Effective degradability }=a+((b \times c) /(c+k))
$$

where parameters $\mathrm{a}, \mathrm{b}$ and $\mathrm{c}$ as above and $\mathrm{k}=$ the rumen particle outflow rate.

The Statistica for the Windows ${ }^{\mathrm{TM}}$ operating system (StatSoft Inc., 1994) was used for all statistical evaluations. The non-linear curve fitting module was applied to fit the in sacco dry matter degradation data to the equation (1). 


\section{RESULTS}

\section{Chemical composition and mycotoxin contents of feedstuffs}

The crude protein and the $\mathrm{N}$-free extractives content of the Fusarium contaminated wheat was approximately $17 \%$ higher and $4 \%$ lower, respectively, compared to the uncontaminated control wheat (Table 1). The Fusarium contaminated wheat contained approximately $10 \mathrm{mg}$ DON and $0.76 \mathrm{mg} Z \mathrm{ZON}$ per kg dry matter. Traces of these Fusarium toxins were also detected in the control wheat.

\section{Rumen physiological parameters}

The molar proportions of volatile fatty acids in the rumen fluid collected $3 \mathrm{~h}$ after the begin of the morning feeding were not affected by dietary treatments (Table 2). The molar proportions were on average $64,22,10,0.7,1.8$ and $1.5 \%$ for acetic, propionic, butyric, iso-butyric, valeric and iso-valeric acid, respectively. The ratio between acetic and propionic acid was found to be approximately 3 to 1. The concentration of total volatile fatty acids was slightly higher in wethers fed

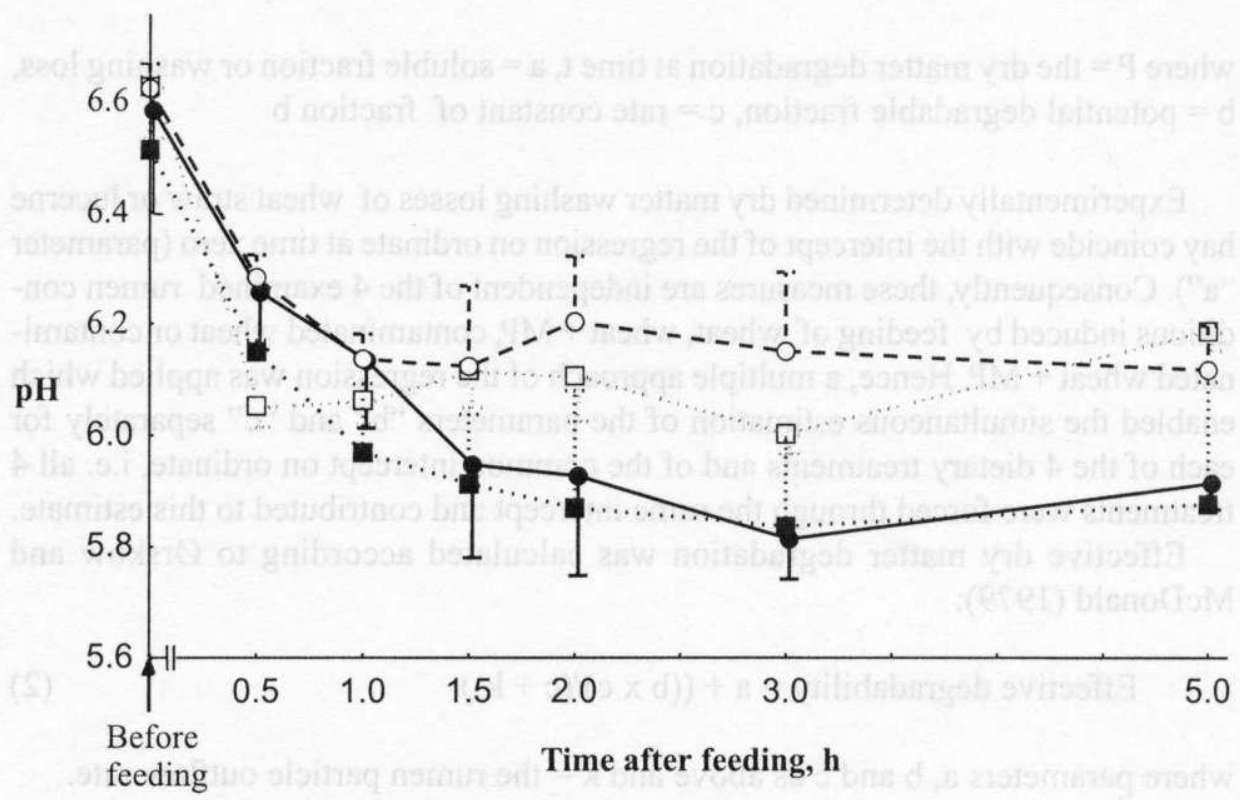

Figure 1. $\mathrm{pH}$ of the rumen fluid in response to control wheat and Fusarium toxin contaminated wheat in the absence and presence of Mycofix ${ }^{\circledR}$ Plus (MP)

- Wheat; - - W- Wheat + Mycofix ${ }^{\circledR}$ Plus; --룰 - Contaminated wheat;

$\longrightarrow$ Contaminated wheat + Mycofix ${ }^{\circledR}$ Plus 


\section{DÄNICKE S.}

密

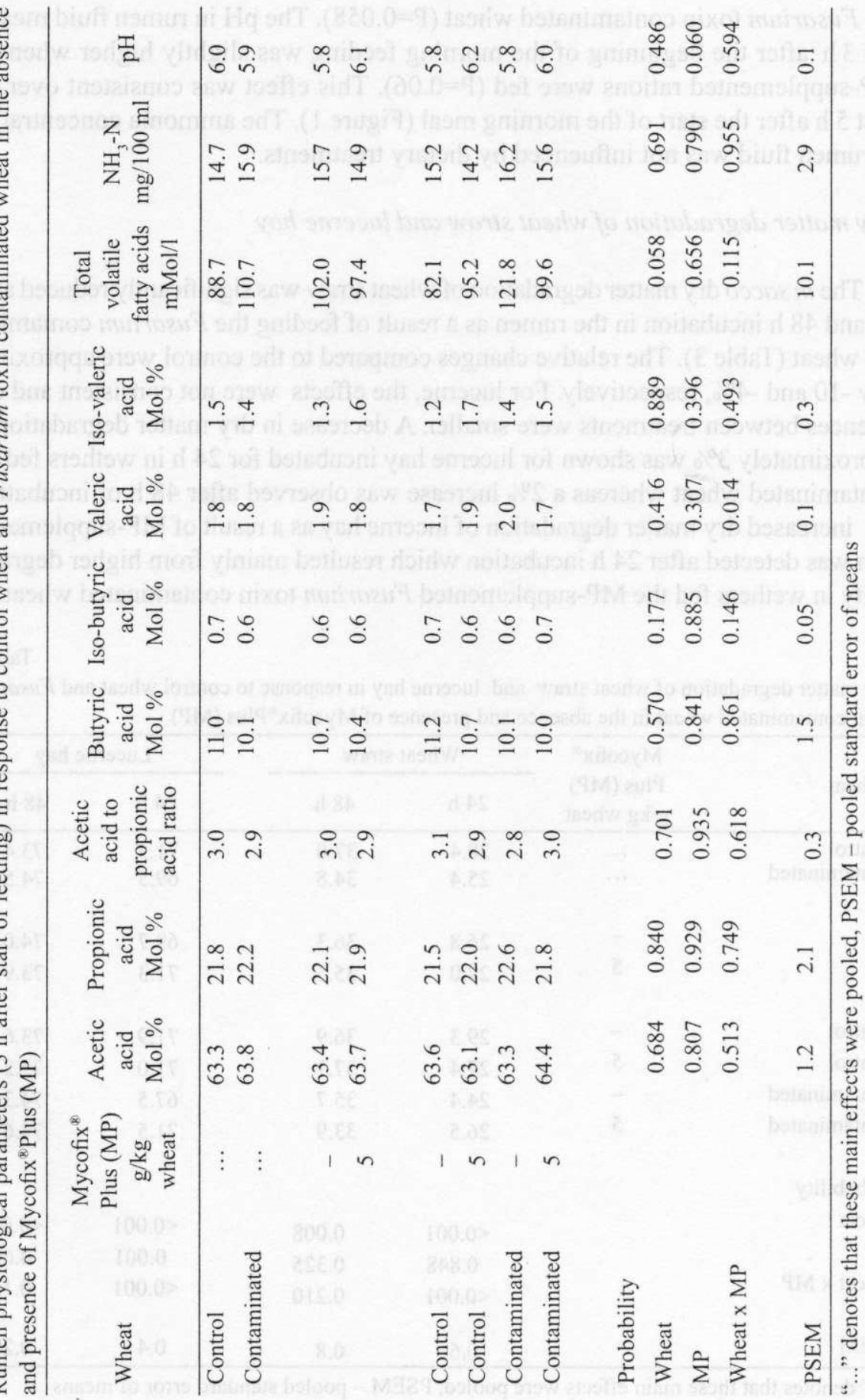


the Fusarium toxin contaminated wheat $(\mathrm{P}=0.058)$. The $\mathrm{pH}$ in rumen fluid measured $3 \mathrm{~h}$ after the beginning of the morning feeding was slightly higher when the MP-supplemented rations were fed $(\mathrm{P}=0.06)$. This effect was consistent over the first $5 \mathrm{~h}$ after the start of the morning meal (Figure 1). The ammonia concentration in rumen fluid was not influenced by dietary treatments.

\section{Dry matter degradation of wheat straw and lucerne hay}

The in sacco dry matter degradation of wheat straw was significantly reduced after 24 and $48 \mathrm{~h}$ incubation in the rumen as a result of feeding the Fusarium contaminated wheat (Table 3 ). The relative changes compared to the control were approximately -10 and $-4 \%$, respectively. For lucerne, the effects were not consistent and differences between treatments were smaller. A decrease in dry matter degradation of approximately $3 \%$ was shown for lucerne hay incubated for $24 \mathrm{~h}$ in wethers fed the contaminated wheat whereas a $2 \%$ increase was observed after $48 \mathrm{~h}$ of incubation. An increased dry matter degradation of lucerne hay as a result of MP-supplementation was detected after $24 \mathrm{~h}$ incubation which resulted mainly from higher degradability in wethers fed the MP-supplemented Fusarium toxin contaminated wheat.

Table 3

Dry matter degradation of wheat straw and lucerne hay in response to control wheat and Fusurimm toxin contaminated wheat in the absence and presence of Mycofix ${ }^{k}$ Plus (MP)

\begin{tabular}{|c|c|c|c|c|c|}
\hline \multirow{2}{*}{ Wheat } & \multirow{2}{*}{$\begin{array}{l}\text { Mycofix" } \\
\text { Plus (MP) } \\
\text { g/kg wheat }\end{array}$} & \multicolumn{2}{|c|}{ Wheat straw } & \multicolumn{2}{|c|}{ Lucerne hay } \\
\hline & & $24 \mathrm{~h}$ & $48 \mathrm{~h}$ & $24 \mathrm{~h}$ & $48 \mathrm{l}$ \\
\hline \multirow{4}{*}{$\begin{array}{l}\text { Control } \\
\text { Contaminated }\end{array}$} & $\ldots$ & 28.4 & 37.0 & 71.5 & 73.4 \\
\hline & $\cdots$ & 25.4 & 34.8 & 69.5 & 74.5 \\
\hline & - & 26.8 & 36.3 & 69.7 & 74.0 \\
\hline & 5 & 27.0 & 35.5 & 71.3 & 73.9 \\
\hline Control & - & 29.3 & 36.9 & 71.9 & 73.6 \\
\hline Control & 5 & 27.4 & 37.1 & 71.0 & 73.2 \\
\hline Contaminated & - & 24.4 & 35.7 & 67.5 & 74.3 \\
\hline Contaminated & 5 & 26.5 & 33.9 & 71.5 & 74.6 \\
\hline \multicolumn{6}{|l|}{ Probability } \\
\hline Wheat & & $<0.001$ & 0.008 & $<0.001$ & $<0.001$ \\
\hline MP & & 0.848 & 0.325 & 0.001 & 0.681 \\
\hline Wheat x MP & & $<0.001$ & 0.210 & $<0.001$ & 0.156 \\
\hline PSEM & & 0.6 & 0.8 & 0.4 & 0.2 \\
\hline
\end{tabular}

"..." denotes that these main effects were pooled, PSEM - pooled standard error of means 
Mean values of dry matter degradation were fitted to equation (1) according to the procedure outlined in the "Statistics" section. The estimated regressions are shown in Figure 2 for both incubated feedstuffs. The respective regression parameters are summarized in Table 4. The multiple determination measure was greater than 0.99 and corresponded to a residual standard deviation of approximately $1.7 \%$ dry matter degradation which could not be explained by the applied regression approach.

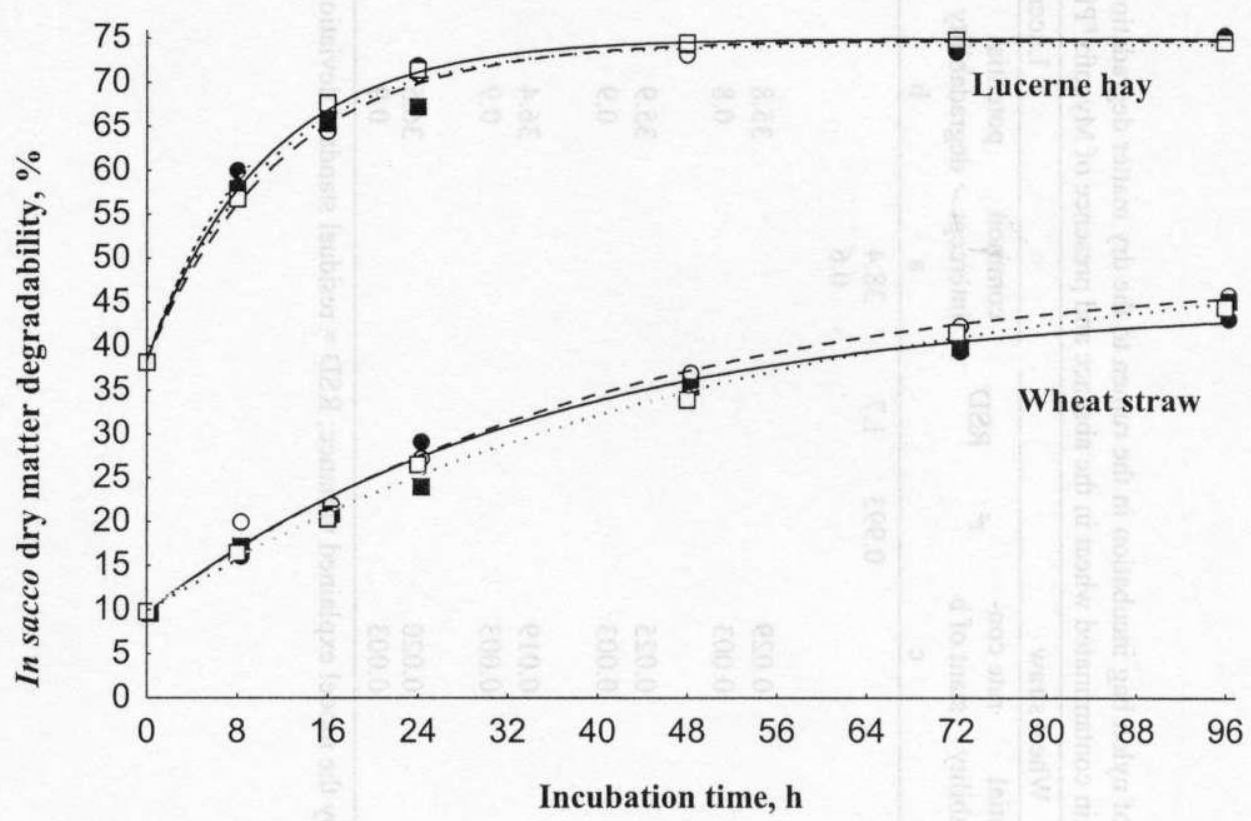

Figure 2. Dry matter degradability of wheat straw and lucerne hay in response to control wheat and Fusarium toxin contaminated wheat in the absence and presence of Mycofix ${ }^{18} \mathrm{Plus}$ (MP)

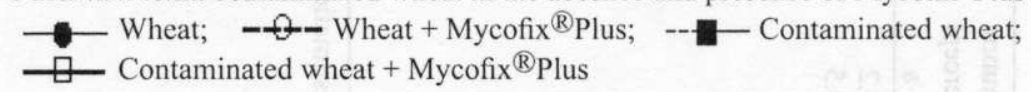

The intercepts on ordinate (a) were estimated simultaneously by inclusion of all 4 treatment data pairs for either wheat straw or lucerne hay and were 10.2 and $38.4 \%$, respectively. These estimates were close to the measured washing losses (Figure 2). The regressions were forced through a common intercept on ordinate (= estimated washing losses, parameter "a") since washing losses, either measured or estimated, were not dependent on dietary treatments.

The potential degradable insoluble fraction (b) was approximately $11 \%$ higher when wheat straw was incubated in wethers fed the contaminated wheat whereas practically no difference was observed when lucerne hay was incubated. The 
ป

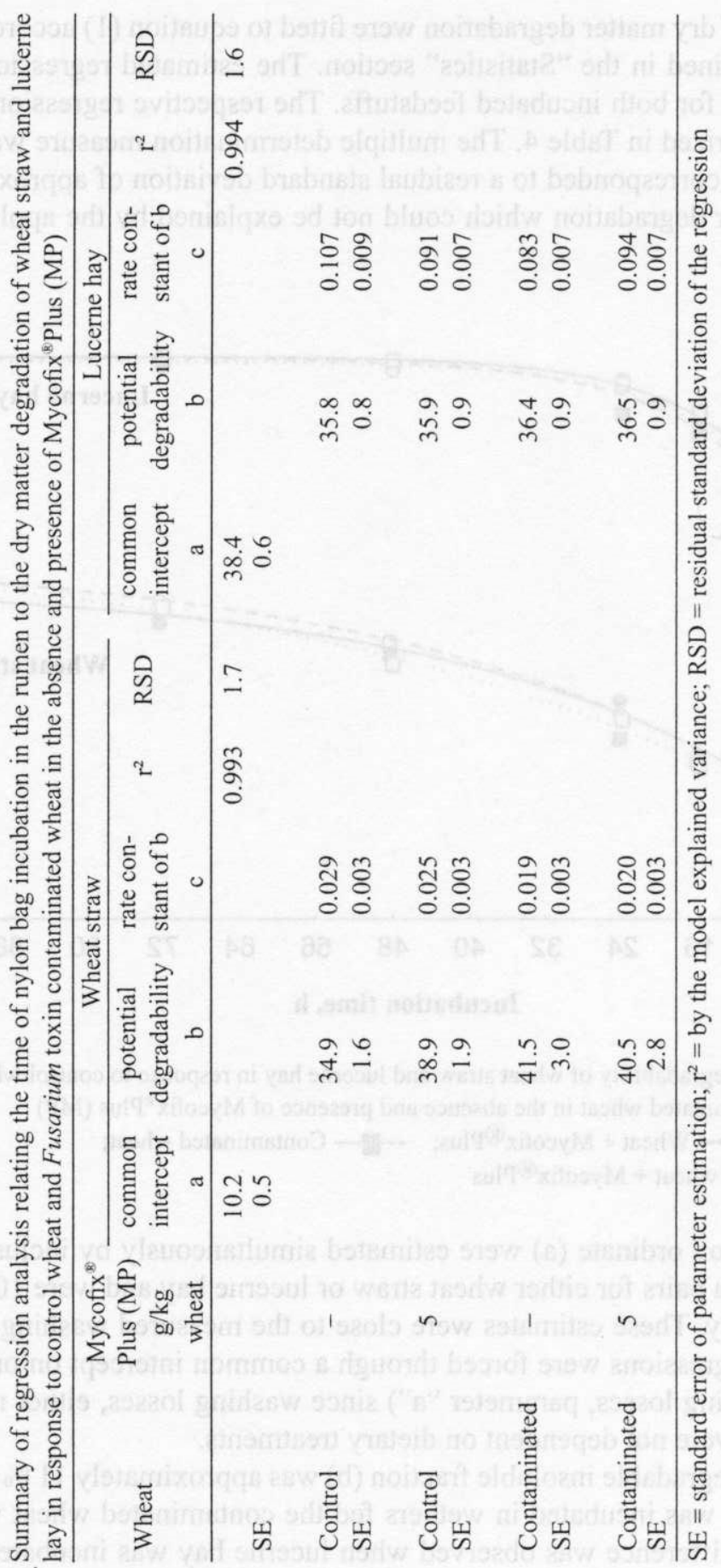


corresponding rate constants (c) were approximately 28 and $11 \%$ lower for wheat straw and lucerne hay, respectively, when incubated in wethers fed the mycotoxin containing wheat.

The effective dry matter degradation was estimated assuming 2 different rumen outflow rates (Figure 3 ) for evaluation of possible consequences of different levels of feed intake on dry matter degradation. It was clearly lower for wheat straw than for lucerne hay and decreased with increasing feed passage rate.

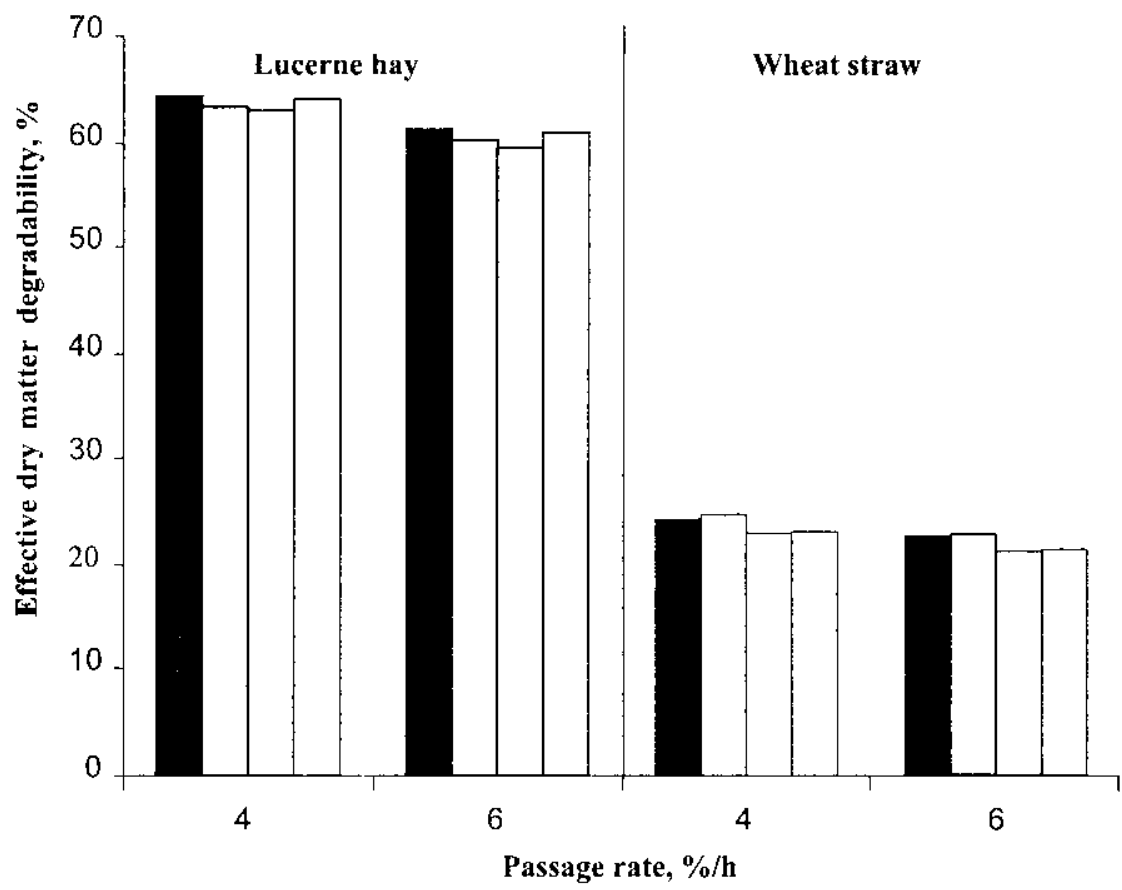

Figure 3. Effective dry matter degradability of wheat straw in response to control wheat and Fusarium toxin contaminated wheat in the absence and presence of Mycofix $x^{\text {"Plus }}$ (MP) modeled for different rumen particle outflow rates

$\longrightarrow$

Wheat; Wheat + Mycofix ${ }^{\mathbb{R}}$ Plus; Contaninated wheat;

Contaminated wheat + Mycofix ${ }^{\text {PP Plus }}$

\section{DISCUSSION}

The in situ technique is extensively used for evaluation of roughages and many attempts have been made to relate the results of in sacco degradation kinetics to nutrient digestibility and feed intake in order to predict performance (for review see Ørskov, 2000). The primary aim of the present study was to examine how a ruminal environment highly "enriched" with Fusarium toxins and their metaboli- 
tes influences the microbial capacity for dry matter breakdown of lucerne hay and wheat straw. These feedstuffs were used as roughages with known marked differences in degradation kinetics. Mycotoxins are known to exert anti-microbial properties (Trenholm et al., 1989). Therefore, the hypothesis was tested if possible mycotoxin induced changes in the rumen microbial profile and/or microbial activity could also modify the ruminal capacity for dry matter degradation of lucerne hay and wheat straw as quickly and slowly degradable roughages, respectively. Generally, feeding of the contaminated wheat variants resulted in a significantly lower dry matter degradation. This depression was more pronounced for wheat straw than for lucerne, especially at the beginning of the incubation during the first $24 \mathrm{~h}$. The latter time-dependent effect is clearly reflected by the differences in the rate constants of the exponential regression (c) which were 28 and $11 \%$ lower when estimated for wheat straw and lucerne hay, respectively, incubated in wethers fed the contaminated wheat and neglecting the MP-effect. The potential insoluble degradable fraction (b) was increased at the same time; an effect which is closely linked to the lower degradation rate. Therefore, the parameter " $b$ " could be overestimated due to a less pronounced plateau of degradation (Figure 2, wheat straw) as a result of a too short total incubation duration for the slowly degradable wheat straw.

The lower rate constants due to feeding of the contaminated wheat resulted also in a lower effective dry matter degradability (Figure 3). Although degradability of lucerne hay and wheat straw was only approximately $1 \%$ lower when incubated in wethers fed the contaminated wheat, the relative decrease was approximately $6 \%$ for wheat straw when compared to lucerne hay ( $1 \%$ relative decrease) at a passage rate of $6 \%$. Increasing the passage rate from 4 to $6 \%$ (Figure 3 ) also decreases the dry matter degradability of wheat straw to a greater extent than that of lucerne hay ( 14 and $5 \%$ relative decrease, respectively) when treatment effects (wheat batch, MP addition) are neglected.

It could be shown that the correlations between in sacco dry matter and NDF degradation were higher than 0.99 for maize residues (Parys, 2001). Therefore, it might be deduced for the present study that the differences in dry matter degradation kinetics of wheat straw were mainly due to differences in NDF or cell wall degradation. This is substantiated by the fact that wheat straw is composed of approximately $80 \%$ NDF (Table 1). Thus, neither a Fusarium toxin nor a nutrient mediated depression of cellulolytic microorganisms and/or their activity can be excluded since wheat batches differed not only in mycotoxin concentration but also in protein and other nutrient content (Table 1).

Wethers were in a steady feeding state and consumed $6.2 \mathrm{mg}$ DON and 0.46 $\mathrm{mg}$ ZON daily which is equivalent to a DON- and ZON-concentration of 4.6 and $0.34 \mathrm{mg} / \mathrm{kg}$ at a reference dry matter content of $88 \%$. No reduction in feed intake was seen at these mycotoxin levels. On the other hand, crude protein intake was 
$18 \%$ higher when the Fusarium toxin contaminated wheat was fed because wheat was fed at a constant amount of $600 \mathrm{~g}$ dry matter per day. Therefore, it can not be differentiated between mycotoxin and nutrient effects in interpreting the differences in wheat straw degradation.

Rumen $\mathrm{pH}$, concentrations of $\mathrm{NH}_{3}$ and volatile fatty acids or their molar proportions were not affected by the two wheat batches. Therefore, the recorded changes in wheat straw dry matter degradation were not reflected by rumen physiological parameters and could consequently be of limited importance under practical feeding conditions, which is supported by an unchanged liveweight gain of growing bulls fed the same wheat batches as used in the present study (Dänicke et al., 2002).

The most striking effect in the present study was the pH-buffering effect of the detoxifying agent which was independent of Fusarium toxins since it was observed for both wheat batches. According to the manufacturer, the used detoxifying agent is composed of an adsorbing and an enzymatic component (Pasteiner, 1998). Beneficial effects of natural adsorbing substances such as bentonite and zeolite in buffering the $\mathrm{pH}$ in the rumen and in prophylaxis of rumen acidosis have been reported (Hampel and Jacobi, 1986). These effects are caused by the affinity of such adsorbents to protons. Thus, the $\mathrm{pH}$-increasing effects of MP could be related to its adsorbing component. The typical fall in $\mathrm{pH}$ due to feeding was buffered by $\mathrm{MP}$ and was consistent from $1.5 \mathrm{~h}$ after the beginning of feeding up to the end of measurements after $5 \mathrm{~h}$ (Figure 1). The $\mathrm{pH}$-differences in rumen fluids collected from wethers fed the MP-supplemented and unsupplemented rations amounted 0.2 to 0.3 on average in the time period between 1.5 and $5 \mathrm{~h}$ after feeding. The pH-buffering effect of MP was not accompanied by changes in the concentration of total volatile fatty acids or by shifts in their molar proportions, which might be an indication that the $\mathrm{pH}$-buffering MP-effects were of little physiological importance. This is supported by the fact that only little or no effect of MP on in sacco dry matter degradation were observed since literature reports have revealed that a sub-optimal low rumen $\mathrm{pH}$ decreases the digestibility of organic matter due to a depression in fibre digestibility (e.g., de Veth and Kolver, 2001).

Summing up, the effects of a wheat batch contaminated with the dominating Fusarium toxins DON and ZON on rumen fermentation were rather low with the exception that the rate of dry matter degradation of wheat straw was slowed down. The main effect of the detoxifying agent was a mycotoxin-independent buffering of the rumen $\mathrm{pH}$. Practical consequences of these findings need to be examined further. 


\section{REFERENCES}

Blüthgen A., Heeschen W., 1990. Zum Einfuß einer Zufütterung von Bentonit auf die Aflatoxin $M_{1}$ Ausscheidung in der Milch. Lebensm. Ind. Milchwirtsch. 29, 955-957

Blüthgen A., Schwertfeger M., 2000. Ausscheidung von Atlatoxin M, mit der Milch laktierender Kühe nach simultaner Zufütterung adsorptiver Zusatzstoffe und Aflatoxin $\mathrm{B}_{1}$ - Versuche in vivo und in vitro. Kicl. Milchwirt. Forschungsber. 52, 145-164

BML, 2000. The German Federal Ministry of Agriculture: Orientation values for critical concentrations of deoxynivalenol and zearalenone in diets for pigs, ruminants and gallinaceous poultry. VDM $27 / 00,2-3$

Dänicke S., Gädeken D., Ueberschär K.-H., Scholz H., 2002. Effects of Fusarium toxin contaminated wheat and of a detoxifying agent on performance of growing bulls, on nutrient digestibility in wethers and on the carry over of zearalenone. Arch. Anim. Nutr. (accepted)

de Veth M.J., Kolver E.S., 2001. Diurnal variation in $\mathrm{pH}$ reduces digestion and synthesis of microbial protein when pasture is fermented in continuous culture. J. Dairy Sci. 84, 2066-2072

Diaz D.E., Blackwelder J.T., Hagler j., Hopkins B.A., Jones F.T., Anderson K.L., Whitlow L.W., 1997. The potential of dietary clay products to reduce aflatoxin transmission to milk of dairy cows. J. Dairy Sci. 80, Suppl.1, 261 (Abstr.)

Flachowsky G., Schneider M., Ochrimenko W.I., Richter G.H., Lölmert H.-J., 1988. Methodische Hinweise zur der Nylonbeutel-Teclnnik beim Wiederkäuer. Schriftenreihe Lehrgangseinrichtung Fütterungsberatung, Jena-Remderoda 11.20-26

Geissler Ch., Hoffmann M., Hickel B., 1976. Ein Beitrag zur gaschromatographischen Bestimmung flüchtiger Fettsäuren. Arch.Ticrernähr. 76, 123-129

Hampel I., Jacobi U., 1986. Zur Bedeutung der natürlichen Ionenaustauscher Bentonit und Zeolith (Übersichtsreferat). Monatsschr. Vet.med. 4 1, 238-243

King R.R., McQueen R.E., Levesque D., Greenhalgh R., 1984. Transformation of deoxynivalenol (vomitoxin) by rumen microorganisms. J. Agr. Food Chem. 32, 1181-1183

Mehrez A.Z., Orskov E.R., 1977. A study of the artificial fibre technique for determining the digestibility of feeds in the rumen. J. Agr. Sci, $88,645-650$

Naumann C., Bassler R., 1993. Dic chemische Untersuchung von Futtermitteln. VDLUFA-Verlag, Darmstadt (Germany)

Ørskov E.R., 2000. The in silu technique for the estimation of forage degradability in the ruminants. In: D.I. Givens, E. Owen, R.F.E. Axford, H.M. Omed (Editors). Forage Evaluation in Ruminant Nutrition. CAB International, pp. 175-188

Orskov E.R., McDonald 1., 1979. The estimation of protein degradability in the rumen from incubation measurements weighted according the rate of passage. J. Agr. Sci. 92, 499-503

Parys C., 2001. In sacco-Abbau von Mais-Restpflanzen im Pansen von Milchkühen. Diplomarbeit, Justus-Liebig-Universität, Giessen (Germany)

Pasteiner S., 1998. Mycotoxins in Animal Husbandry. Biomin Gesunde Tierernährung lnternational Gesmbl, Erber AG (Austria)

Razzazi E., Böhm J., Ahmed K.E., Cccon B., Rabus B., 2000. Investigation on the biodegradability of mycotoxins nivaleneol (NIV) and deoxynivalenol (DON) in a rusitec fermentor and their monitoring by HPLC/MS. Mycotox.Res. 16, 4-14

StatSoft Inc., 1994. Statistica for the Windows ${ }^{\text {TM }}$ Operating System Tulsa OK (USA)

Swanson S.P., Nicoletti J., Rood H.D., Buck W.B., Cote L.M., Yoshizawa T., 1987. Metabolism of three trichothecene mycotoxins, T-2 toxin, diacetoxyscirpenol and deoxynivalenol, by bovine rumen microorganisms. J. Chromatogr. 414, 335-342 
Trenholm H.L., Friend D.W., Hamilton R.M.G., Prelusky D.B., Foster B.C., 1989. Lethal toxicity and nonspecific effects. Trichothecene mycotoxicosis: Pathophysiological effects. Vol. 1. V.R. Beasley (Editor). CRC Press Inc., Boca Raton, Florida (USA) pp.107-141

Ueberschär K.-H., 1999. Einfluß von Zearalenon auf Wachstum und Rückstände in den Geweben von Mastkaninchen. VDLUFA-Kongreßband 1999, Halle/Saale, VDLUFA-Schriftenreihe 52, $425-428$

Voigt J., Stecger H., 1967. Zur quantitativen Bestimmung von Ammoniak, Harnstoff und Ketonkörpern in biologischem Material mit Hilfe eines modifizierten Mikrodiffusiongefäßes. Arch. Tiercrnähr. 17, 289-293

\section{STRESZCZENIE}

Wplyw skażenia ziarna toksynami Fusarium oraz czynnika odkażającego na fizjologiczne wskaźniki w żwaczu oraz rozkład in sacco suchej masy słomy pszennej i siana z lucerny, oznaczane na skopach

Przeprowadzono 4 doświadczenia na skopach z trwałymi przetokami żwacza, stosując dawki zawierające ziarno pszenicy i siano łąkowe w stosunku 1:1 w przeliczeniu na suchą masę (s.m.). Skarmiano 2 partie ziarna pszenicy, bez lub z dodatkiem czynnika odkażającego (Mycofix ${ }^{*}$ Płus, Biomin GmbH, Herzogenburg, Austria). Jedna partia pszenicy niezanieczyszczona traktowand była jako kontrolna. druga zawierała toksyny Fusarium: deoxynivalent (DON) i zearalenon (ZON) w stężeniu około 10 i $0,76 \mathrm{mg} / \mathrm{kg} \mathrm{s.m.,} \mathrm{odpowiednio.}$

Nie stwierdzono zmian w proporcji krótkołańcuchowych lotnych kwasów tłuszczowych i stężcniu amoniaku w płynie żwacza jako reakcji na czynniki doświadczalne, natomiast czynnik odkażający buforował pH treści żwacza, lecz efekt ten byl niczależny od zanieczyszezenia ziarna pszenicy mykotoksynami. Różnice pll płynu żwacza między 1,5 a 5 godz. po odpasie skopów kontrolnych i doświadezalnych wynosiły średnio 0,2 do 0,3 .

Tempo rozkładu s.m. słomy pszenncj inkubowanej w żwaczu skopów otrzymujących dawkę zanicczyszczoną mykotoksynami było wolniejsze niż u kontrolnych, nie stwierdzono natomiast różnic w przypadku siana z lucerny. Czynnik odkażający nie miał wpływu na kinetykę rozkładu s.m.

W podsumowaniu stwierdzono, że skarmianie dawek zawierających około 4,6 mg DON i 0,34 mg ZON/kg s.m. dawki nic zakłóca przebicgu fermentacji w żwaczu, choć wystapiła tendencja zmniejszenia tempa rozkładu s.m. wolno rozkładalnej słomy pszennej i nie wpływa na pH treści żwacza. 